\title{
Analysis of Feasibility Level of Integrated Science Practical Guide Book Based on BSNP for Junior High School Grade VII
}

\author{
Agustina M.L. Tobing ${ }^{1}$, Ramlan Silaban ${ }^{2}$, and Nurfajriani ${ }^{3}$ \\ \{agustinatobing90@gmail.com ${ }^{1}$ \} \\ Postgraduate student, Medan State University, Willem Iskandar Pasar V, Medan, Indonesia ${ }^{1}$, \\ Department of Chemistry, Medan State University, Medan, Indonesia ${ }^{2,3}$
}

\begin{abstract}
This study aimed to analyze the feasibility level of the VII grade junior high school integrated science practical guide book. This research was a descriptive analysis study conducted at State Junior High School 10 Medan. This research was limited to the result of feasibility of the practical guide book which is used in 3 schools. Samples of this study were 3 books consisting of 2 LKS books (Student Worksheets) and 1 book created by teacher. Data collection techniques were carried out using a BSNP (National Education Standard Board) questionnaire. This questionnaire is used to assess the feasibility of the guide book. The results of the study show that 1) aspect of feasibility the content in practical guidance integrated guided inquiry model and used school subject have an average of $4.15,2)$ The aspect feasibility of language in practical guidance integrated guided inquiry model and used school subject average of 4.00,3) The aspect feasibility of presentation in practical guidance integrated guided inquiry model and used school subject have an average of $4.06,4)$ The aspect feasibility of graphing in practical guidance integrated guided inquiry model and used school subject have an average of 4.08 .
\end{abstract}

Keywords: Analysis, Practical guide book, Questionnaire

\section{Introduction}

Education is an effort made by humans consciously and sustainably to gain knowledge widely both cognitive, psychomotor, affective and good skills needed by themselves and society. According to the Law on National Education System Number 20 of 2003, "education is a conscious and planned effort to realize a learning atmosphere and learning process so that students actively develop their potential to have religious spiritual strength, self-control, personality, intelligence, noble character and the skills needed by him, the community, the nation and the State. "

One effort to improve the quality of education in Indonesia is through efforts to improve the teaching and learning process at all levels of education. The quality of education in Indonesia needs to be seen by some influencing elements, such as curriculum, educational content, learning process, evaluation, teacher quality, school facilities and infrastructure and textbooks. (Handayani, et al. 2014).

With the enactment of the 2013 curriculum, which is a curriculum that can produce Indonesian people who are: productive, creative, innovative, affective through strengthening 
integrated attitudes, skills and knowledge and having 4 major changes, namely: (1) a balanced curriculum concept between hardskill and soft skills starts from Competency Standards for Graduates, Content Standards, Process Standards, and Assessment Standards (2) The use of student books is more emphasized in the activity base is not a reading material (3) Each book contains learning models and (4) projects that students will do and an assessment process that supports student creativity. (Winarso, 2015)

Based on the interviews and the results of the analysis of the integrated science worksheet taken from the three schools, there were some disadvantages including (1) the absence of the number of equipment used, (2) the absence of specifications and MSDS from the materials used, (3) the presentation of work safety not attached, (4) in some experiments there are no questions that explore the curiosity of students, (5) practicum made only covers a number of $\mathrm{KD}$, (6) goals that are not listed in some experiments, (7) book skin illustrations have not provided an overview of the material teach science, and so on

In connection with this matter, it is necessary to have a practical guide specifically designed for junior high school science lessons. Through the integration of scientific learning models with practicum so that it can create quality learning outcomes and human resources with character.

\section{Literature}

\subsection{Research and Development}

Research and Development is a research that is directed to produce products, designs, and processes. In the world of education and learning, especially development research focuses its study on the field of design or design, in the form of design and design models of teaching materials and products such as media and learning processes. (Setyosari, 2012). According to Gay (1990), development research is an attempt to develop a product that is effective for school use, and not to test theory. Whereas Borg and Gall (1983) define development research as a process used to develop and validate educational products.

The Dick \& Carey development model consists of ten steps, namely needs analysis, learning analysis, learning analysis and context, general and specific goals, developing instruments, developing learning strategies, developing and selecting teaching materials, designing and conducting formative evaluation, revision and evaluation sumative.

Borg \& Gall (1983) proposed a series of steps that must be taken in this approach, namely: "Research and information collecting, planning, develop preliminary form of product, preliminary field testing, main product revision, main field testing, operational product revision, operational field testing, final product revision, and dissemination and implementation".

\subsection{Curriculum 2013}

Development of the 2013 Curriculum is a further step in the development of the Competency Based Curriculum which was initiated in 2004 and the 2006 KTSP which includes integrated competencies in attitude, knowledge, skills. Then, with regard to national education objectives, it is affirmed in Law Number 20 Article 3 of 2003, namely: Educated 
humans who believe and fear God Almighty, are noble, healthy, knowledgeable, capable, creative, independent, and become citizens democratic and responsible.

The 2013 curriculum aims to prepare Indonesian people to have the ability to live as individuals and citizens who are faithful, productive, creative, innovative, and affective and able to contribute to the life of society, nation, state and world civilization.

\subsection{Development of Integrated Science Learning in 2013 Curriculum}

The development of integrated science learning broadly includes three main activities, namely: planning, implementation, and assessment.

a. Planning

Planning for integrated science learning is carried out by considering the conditions and potential of students (interests, talents, needs, and abilities of students), as well as other supporting resources (teacher ability, availability of learning facilities and infrastructure, and concern of stakeholders in schools (Kemdikbud, 2013) Activities in planning activities include:

1. Identify the science concept in one $\mathrm{KD}$ through an analysis of the Graduates Competency Standards (SKL), Core Competencies (KI), and Basic Competencies (KD).

2. Determine the integrated model (connected, webbed, sharedand integrated).

3. Creating a concept / matrix / map relationship concept in $\mathrm{KD}$ with the theme / topic of integration.

4. Formulate indicators.

The formulation of links and the selection of topics in integrated science learning must be relevant to the integrated $\mathrm{KD}$. These activities are also made by paying attention to issues that are actual, interesting, and contextual so as to foster the curiosity of students who have a sustainable effect in the form of seeking answers to curiosity through discovery. Examples of the flow of the IPA concept mapping in the Ministry of Education and Culture (2013) are illustrated in Figure 2.1.

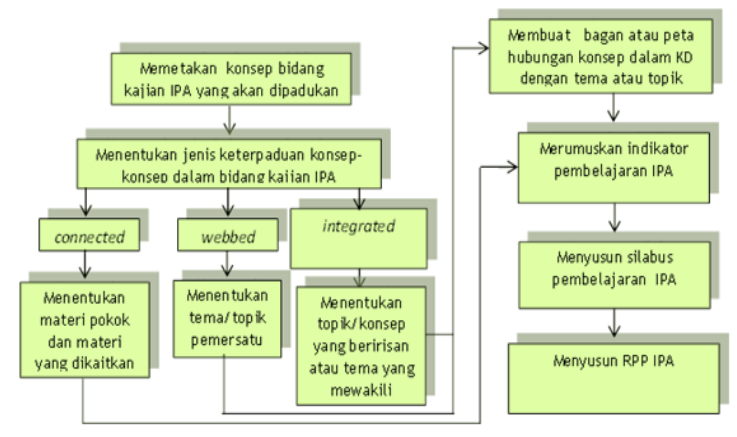

Fig. 1. Flowchart of the science concept mapping (Kemdikbud, 2013)

b. Learning Implementation

The implementation of learning is contained in the RPP as outlined in the syllabus. Learning activities start from preliminary, core and closing activities and are carried out with a scientific approach (asking, observing, processing, presenting, concluding, and creating). The 
step or learning syntax is modified according to the selected integration model. Examples of integration models with the topic "Mixed Separation" are presented in Figure 2.2.

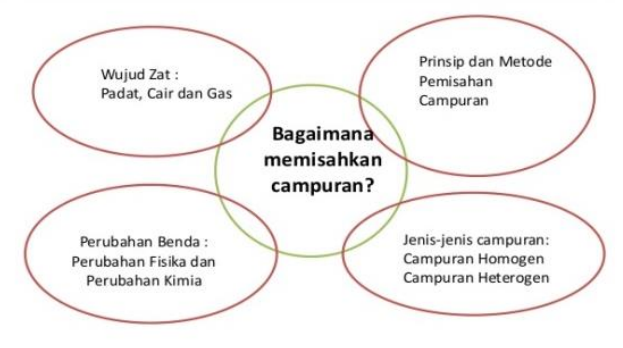

Fig. 2. Models connected with mixed separation topics

(Kemdikbud, 2013)

\subsection{Feasibility Standards According to BSNP}

a. Assessment of primary and secondary education textbooks issued by the National Education Standards Board (BSNP) consists of special instruments in the form of questionnaires with certain scoring. Each book assessment instrument in the National Education Standards Agency (BSNP) contains items of assessment and descriptions that are used as a reference in assessing the quality of textbooks so that the textbooks can be used in the learning process. Assessment instrument for textbooks based on the National Education Standards Agency (BSNP) consists of two stages and a score for each component is included. This conformity analysis with the National Education Standards Agency (BSNP) is carried out with reference to first and second stage. Each stage of the assessment of lesson textbooks contains components and assessment items that can be described as follows:

a. The First Stage Assessment Instrument

1. Components of content eligibility

a) Competency standards (SK) are implicitly listed

b) Basic competencies (KD) are implicitly listed

c) Compatibility of book contents with competency standards (SK) and basic competencies (KD). (BSNP, 2006)

2. Component of Presentation

a) Table of contents

b) The purpose of each chapter

c) Concept map or summary

d) Key words

e) Questions / practice questions in each chapter

f) Bibliography

3. Graphical components
a) Book skin
b) Fill in the book
c) Readability (suitability in the selection of letters, illustrations and formats) 
d) Quality of prints (clarity, flatness and print color)

e) Physical strength of books (fill paper, leather material, and binding system)

b. The Second Stage Assessment Instrument (Sub Component)

1. Components of content eligibility
a) material coverage
b) material accuracy
c) up-to-date
d) contains insight into productivity
e) stimulate curiosity (curiosity)
f) develop life skills
g) develop a sense of diversity
h) contains contextual insight

2. Linguistic Components

a) according to the level of development of students

b) communicative

c) dialogical and interactive

d) straightforward

e) coherence and thoughtfulness of the flow of thought

f) conformity with Indonesian language rules

g) use of terms and symbols / symbols

3. Components of presentation

a) presentation techniques

b) supporting material presentation

c) presentation of learning

4. Graphical component

a) book size

b) the leather part of the book

c) section of book contents (BSNP, 2006)

\subsection{Curriculum 2013}

Inquiry modelis a core partofthe contextualbased learningactivities. Knowledgeand skillsstudents are expectednotfrom the resultsgivenset of facts, butthe result of findingits own(Trianto, 2010).Inquiry modelis a processthat variesandincludesactivitiesto observe, to formulaterelevant questions, evaluatingbooks andother informationsourcescritically, planinvestigation, reviewingwhat is already known, carry outexperiments toobtain data, analyze and interpret dataand communicateresult(Suyanti, 2010).Inquiry model is a teaching method that tries to put the base and develop a scientific way of thinking. In applying this method more students are required to learn on their own and trying to develop creativity in development a problem that it faces its own. Inquiri teaching methods will create conditions conducive to effective learning and, as well as simplify and expedite the learning activities (Sudjana, 2004). 


\section{Research Method}

This research uses research and development ( R \& D) method. This research has been conducted in Junior High School in Medan, North Sumatra. The study was conducted in September-October 2018.

The population in this study is science teachers in junior high schools in Medan.

The sample in this study were twenty of science teachers. The teacher sample must be minimum MIPA undergraduate qualification and were actively involved in the laboratory (as a validator of the practicum guide developed). Determination of the sample was done by purposive sampling technique.

The procedure of this study is a modification of the development model by Borg and Gall (1983) and the development model of Dick and Carey (2005) which becomes 5 stages, including: analysis phase, development stage, validation stage, revision stage and evaluation stage. but in this study only focused to the analysis of research stage stage by 20 science teachers. In summary, the flow of the research procedure is shown in Figure 3.1.

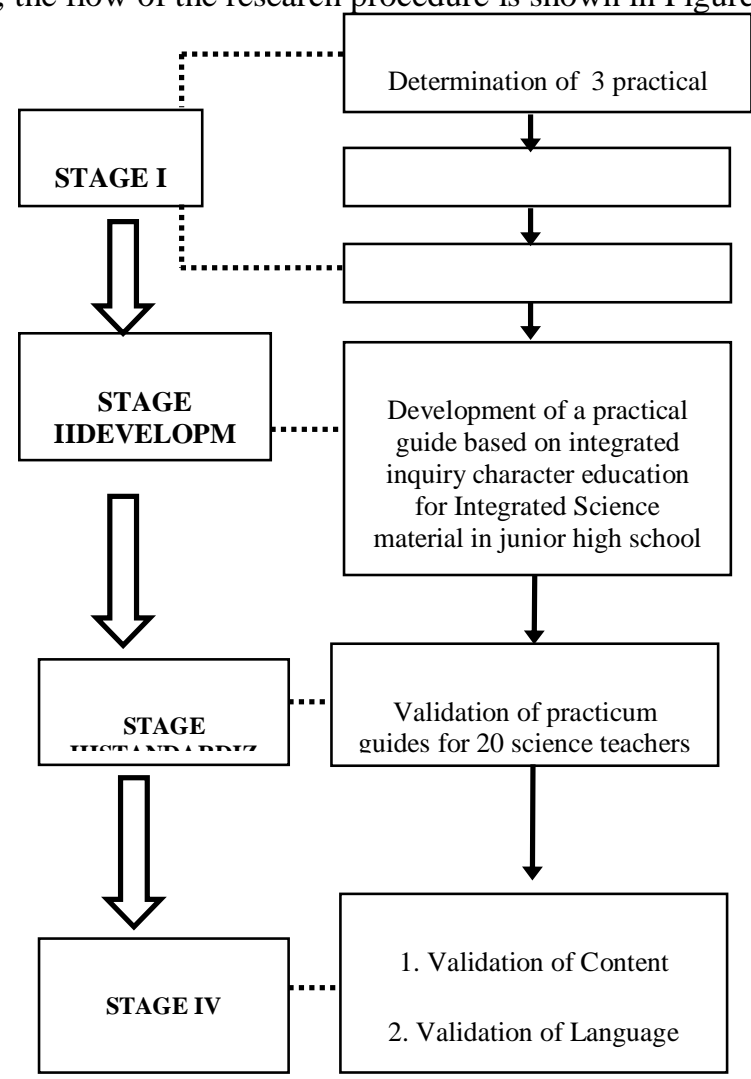

Fig. 3. The development stage of the integrated science practicum guide based on integrated guided inquiry on character education.

In this research used a questionnaire to validation of practical guidance with the scale of research used to analyze the standard of teaching materials is 1 to 5 . Where 1 as lower score and 5 as higherscore. Determination of the range can be known through the highest scores 
range reduced range of the lowest score divided by the highest score. The criteria for the validity of the analysis of the average used can be seen in Table 3.1 below:

Table 1. Validity Criteria Analysis Average Score

\begin{tabular}{|c|c|}
\hline Average & Criterion Validity \\
\hline 4,75 & - Valid and not need revision (very decent) \\
\hline 5,00 & \\
\hline 3,26 & Valid and not need revision (decent) \\
\hline 4,00 & \\
\hline 2,51 & - Sufficiently valid and does not need \\
\hline 3,25 & revision (sufficient) \\
\hline 1,76 & - Less valid, most of the contents of the \\
\hline 2,50 & book needs to be revised (less decent) \\
\hline 1,00 & - Invalid and need revision total (not \\
\hline 1,75 & decent) \\
\hline
\end{tabular}

\section{Result And Discussion}

This research was conducted on the science practice manual for junior high school written by Pratama Mitra Aksara, Mediatama and the teacher's own essay. Feasibility analysis is carried out on aspects of content, language, presentation and graphics.

I. Aspect of Feasibility Content

There are eight (8) components indicator feasibility of contents standarization in practical guidance chemistry integrated guided inquiry model grade XI in high school, namely : 1) suitability practicum with the material; 2) The purpose of practicum ; 3) Basic theory; 4) Tools of practicum; 5) Material of practicum; 6) Procedure of experiment ; 7) Observation table ; and 8) Questions.

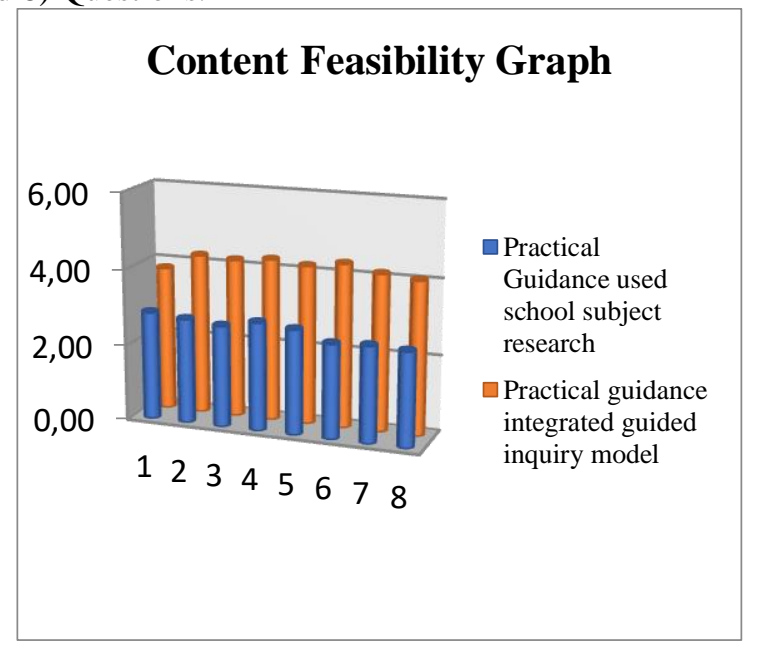

Fig. 4. The Feasibility in Practical Guidance Integrated Guided Inquiry Model and Practical Guidance Used School Research is Based on the Aspect of Feasibility Content. 
II. Aspect of Feasibility Language

There are four (4) components indicator feasibility of language standardization in practical guidance chemistry integrated guided inquiry model grade XI in high school, namely: 1) conformity with the development of learners; 2) Communicative; 3) Compliance with the rules of English language is good and true; 4) The use of terms and symbols.

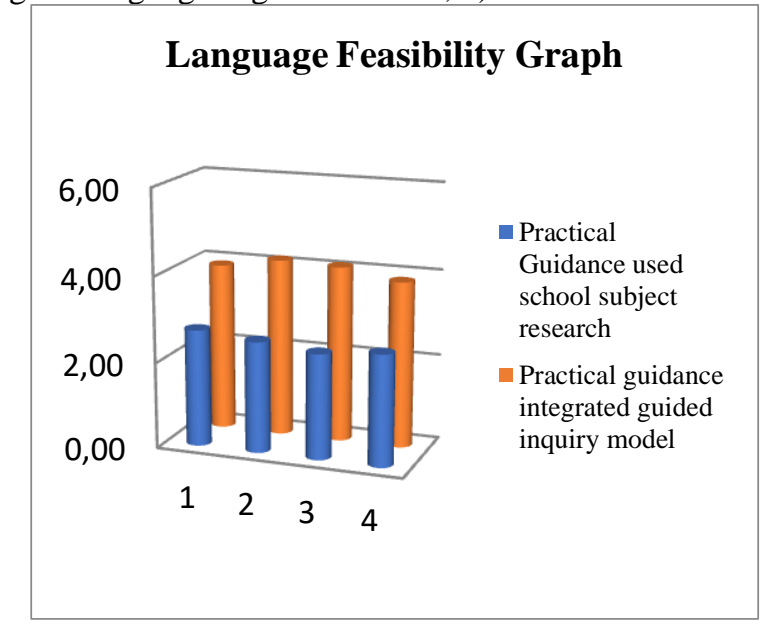

Fig. 5. The Feasibility in Practical Guidance Integrated Guided Inquiry Model and Practical Guidance Used School Research is Based on the Aspect of Feasibility Language.

III. Aspect of Feasibility Presentation

There are four (4) components indicator presentation feasibility of standardization in practical guidance chemistry integrated guided inquiry model grade XI in high school items, namely:1) consistency of systematic in practical guidance ;2) The ability to stimulate the depth of thinking learners; 3) Attachment: Reference; 4) centered on the students.

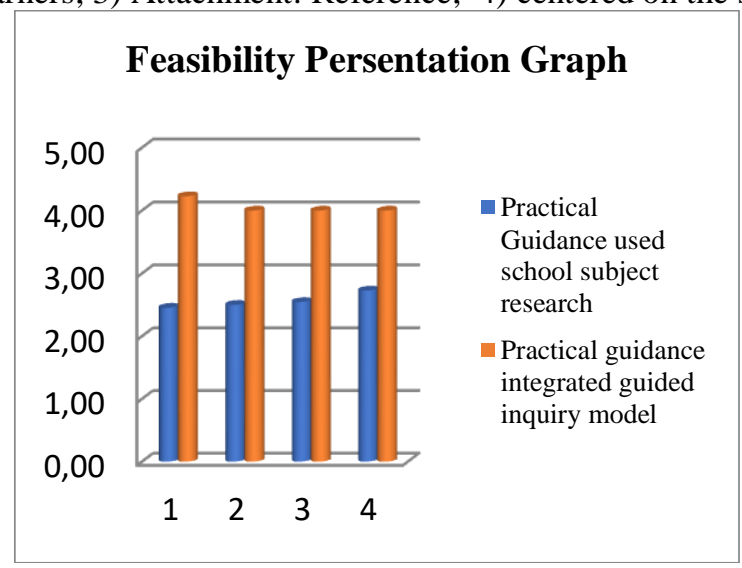

Fig. 6. The Feasibility in Practical Guidance Integrated Guided Inquiry Model and Practical Guidance Used School Research is Based on the Aspect of Feasibility Persentation.

IV. Aspect of Feasibility Graphing 
There are three (3) components indicator presentation feasibility of standardization in practical guidance chemistry integrated guided inquiry model grade XI in high school items, namely: 1) Typographypractical guidance covers; 2) The illustrationpractical guidance covers; 3) Typographycontents of the practical guidance.

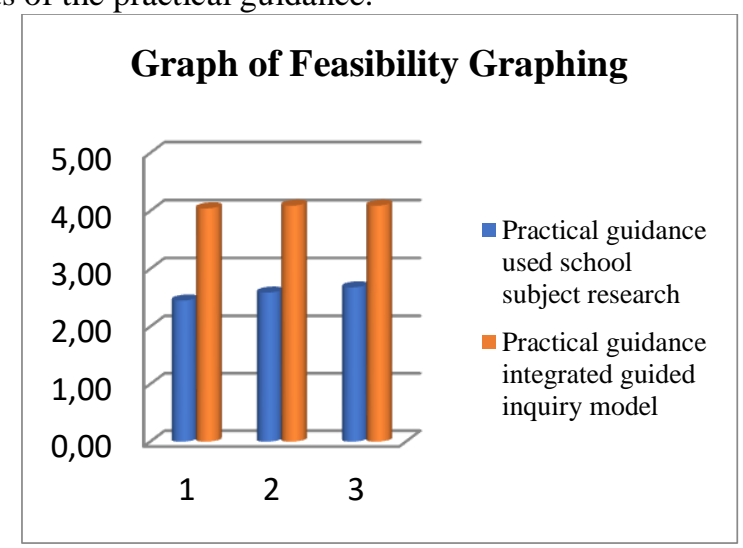

Fig. 7. The Feasibility in Practical Guidance Integrated Guided Inquiry Model and Practical Guidance Used School Research is Based on the Aspect of Feasibility Graphing.

\section{Conclusion}

Based on the aspect of feasibility the content in practical guidance integrated guided inquiry model and used school subject have an average of 4.15 (valid that meaning decent and doesn't need revision) and 2.69 (valid that meaning sufficient and doesn't need revision (sufficient)).The aspect feasibility of language in practical guidance integrated guided inquiry model and used school subject average of 4.00 (valid that meaning decent and doesn't need revision) and 2.59 (valid that meaning sufficient and doesn't need revision). The aspect feasibility of presentation in practical guidance integrated guided inquiry model and used school subject have an average of 4.06 (valid that meaning very decent and doesn't need revision) and 2.56 (valid that meaning sufficient and doesn't need revision). The aspect feasibility of graphing in practical guidance chemistry integrated guided inquiry model and used school subject have an average of 4.08 (valid that meaning decent and doesn't need revision) and 2.58 (valid that meaning sufficient and doesn't need revision).

Acknowledgments. This research was supported by thesis supervisor Prof. Dr. Ramlan Silaban, M.Si. And Dr. Ir. Nurfajriani, M.Si that have given the suggestion in order to complete this research.

\section{References}

[1] Arikunto, S. Prosedur Penelitian Suatu Pendekatan Praktik. Jakarta: Rineka Cipta. (2011)

[2] Borg, W. R. Dan Gall, M. D. Educational Research An Introduction. New York: Longman. (1983)

[3] Badan Standar Nasional Pendidikan (BSNP), Instrumen Penilaian Tahap I Buku Teks Pelajaran Pendidikan Dasar Dan Menengah, (tt.p., BSNP.2006), hlm. 2 (2006) 
[4] Handayani, Lena Putri, Farida F., dan Azwir Anhar. Pengembangan Buku Penuntun Praktikum IPA Berbasis Inkuiri Terbimbing Untuk SMP Kelas VII SemesterII. Jurnal Pendidikan Biologi. (2014)

[5] Somov, A.: Wildfire safety with wireless sensor networks. EAI Endorsed Transactions on Ambient Systems. pp. 1-11 (2011)

[6] Setyosari, P. (2012). Metode Penelitian Pendidikan dan Pengembangan. Jakarta: Prenada Media Group (2013)

[7] Sudjana. Metode Statistika. Bandung: Tarsito (2004)

[8] Suyanti, R.D. Strategi Pembelajaran Kimia. Yogyakarta: Graha Ilmu. (2010)

[9] Winarso, W. Dasar Pengembangan Kurikulum Sekolah. Cirebon. (2015) 